\title{
フィルター処理白血球除去血液製剤中に含まれる漏出白血球の種類
}

\author{
茂木 祐子 細田 真理 高橋 恒夫 関口 定美 \\ 北海道赤十字血液センター
}

(平成 3 年 7 月 29 日受付)

\section{FLOW CYTOMETRIC ANALYSIS OF RESIDUAL LEUKOCYTES IN FILTERED BLOOD COMPONENTS}

\author{
Yuko Mogi, Mari Hosoda, Tsuneo A. Takahashi and Sadayoshi Sekiguchi \\ Hokkaido Red Cross Blood Center
}

Knowing the population of residual leukocytes in filtered blood products is as important as knowing the number of leukocytes to elucidate the mechanisms of the side effects caused by transfused leukocytes and to find ways to prevent them completely. We concentrated residual leukocytes in the filtered red cell concentrates $(\mathrm{RCC})$ and platelet concentrates $(\mathrm{PC})$ by centrifugation with Ficoll-Paque and Percoll respectively, and analyzed the differential population of leukocytes, as well as subpopulations and subsets of lymphocytes using a flowcytometer. Among leukobytes collected from the filtered PC, monocytes were found to be most effectively removed by all the filters tested in this study; the Pa11 PL100, Sepacell PL5N, Imugard PL and Imugard IG-400Y. When using filters made for the RCC, Imugard IG-400Y, Pa11 RC100, Sepacell R-500N, Imugard RC, monocytes are also most effectively removed. Granulocytes tended to come out of filters made of non-woven polyseter fibers (Sepacell R-500N and Pa11 RC100) if the RCC was fresh and filtered above $4^{\circ} \mathrm{C}$. B cells were removed more effectively than $\mathrm{T}$ cells by filters made for RCC. On the other hand the specificity to the $\mathrm{B}$ cells of filters made for PC was much less than that observed using the filters made for RCC. CD8 ${ }^{+}$ cells were more specifically removed by the filters made for PC. Among the RCC filters, the Imugard $\mathrm{RC}$ filter made of microporous polyvinyl alcohol could remove $\mathrm{CD} 8^{+}$cells most effectively. The filters made for RCC removed NK cells more effectively than T cells, but the filters made for PC did not show specificity to NK cells.

This study should help to clarify the mechanisms of alloimmunization and viral infection transmitted by specific leukocytes and also to elucidate the mechanism of leukocyte-depletion by filters, which are not perfectly understand at present.

\section{緒 言}

全血 (WB : whole blood), 濃厚赤血球 (RCC: red cell concentrate), 濃厚血小板 (PC: platelet concentrate) といった製剤中には 1 単位あたり $10^{7} \sim 10^{9}$ 個レベルの白血球が含まれている1).この 白血球が原因となる輸血副作用としては, 非溶血 性発熱反応, 同種免疫抗体の発現とそれに伴う血 小板輸血不応状態, 輸血後ウイルス感染 (HTLVI, CMV, HIV 等), 輸血後 GVHD (graft-versushost disease）等がある12). これらの副作用の中 で, 非溶血性発熱反応については白血球を $10^{8}$ 個程
度まで除去した製剤を用いれば防ぐことが出来る が3) 5), 同種免疫の予防には $5 \times 10^{6}$ 個あるいは $1 \times$ $10^{6}$ 個以下に白血球数を減らす必要があると考兄 られている2,6) 8). CMV 感染は血液製剂当りの白 血球数を107個以下にすれば防止でき9)，HTLV-I 感染は $10^{8}$ 個以上のリンパ球の存在が感染に必要 と言われている(10). 一方輸血後 GVHD はょり少 ないリンパ球でも起こる可能性がある1112). さら にこれらの副作用はそれぞれ特異的な白血球に よって引き起こされることも明らかになりつつあ $ろ^{13144)}$. この輸血副作用の原因となる白血球を除 
去するためのフィルターの開発は近年めざましい ものがあり，材質の異なる様々な白血球除去フィ

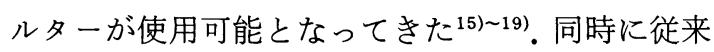
その正確な測定が困難とされた，フィルター処理 によっても漏出してくるごくわずかな数の白血球 を測定する方法も考案されてきている20) 25). しか しフィルター処理前後の血液製剂中の白血球数を 知るのみでなくその種類, リンパ球のサブポピュ レーションおよびサブセットを知ることは, 輸血 副作用の予防やその発症の機序を解明していく上 で極めて重要である。

今回我々は, $400 \mathrm{~m} l$ 献血由来の $\mathrm{WB} \cdot \mathrm{RCC} \cdot \mathrm{PC}$ 执よびアフェレーシス $\mathrm{PC}$ ，さらに種々のフィル ターで処理した RCC およびPCに含まれる白血 球の数と種類(顆粒球, リンパ球, 単球), リンパ 球のサブポピュレーションおよびサブセットを, フローサイトメトリー（FCM : flow cytometry） によって測定したので報告する。

\section{材料と方法}

\section{1. 血液製剂の調製}

$56 \mathrm{~m} l$ の抗凝固液 CPD (citrate phosphate dextrose)を含むトリプルバッグに健常人から採血し た $400 \mathrm{~m} l$ の WB $, 1,100 \times \mathrm{g}$ で 5 分間 $20^{\circ} \mathrm{C}$ で遠 心し， RCC と多血小板血墏 (PRP : platelet rich plasma）に分離した. PRP はさらに $3,200 \times \mathrm{g}$ で 十分間遠心して血小板ペレットと乏血小板血漿 (PPP : platelet poor plasma) に分離し，ペレッ トに $40 \mathrm{~m} l$ のPPを戻して PCとした. WB と $\mathrm{RCC}$ は採血当日に, $\mathrm{PC}$ は分離後室温で 1 時間静 置した後, 水平振盪保存 $\left(60 \mathrm{rpm}, 20 \sim 22^{\circ} \mathrm{C}\right)$ して 翌日測定を行った。フィルター処理は RCC は採 血当日もしくは $4{ }^{\circ} \mathrm{C} て ゙ 1$ 日保存したもの, また $\mathrm{PC}$ は $200 \mathrm{~m} l$ 全血由来 $\mathrm{PC} 1$ 単位（平均 $2.4 \pm$ $0.7 \times 10^{10}$ 個の血小板を含む) として採血後 1 日保 存した後 20 単位プールしたものを用いた。

アフェレーシス PCは, Fenwal CS-3000 (Baxter, Deerfield, IL, USA)を用いて，採血時間約 90分, 全血と ACD (acid citrare dextrose) 液の 比率を11：1として PC 約10〜15単位分を採取し た。

2.フィルター処理
$\mathrm{RCC}$ のフィルー処理は, ポリエステル不織布 からなるポール RC100（Pall RC100：Pall Co., Glen Cove, NY, USA) およびセパセル R-500N (Sepacell R-500N : 旭メディカル, 東京), ポリビ ニルアルコール系多孔質体からなるイムガード RC(Imugard RC：テルモ，東京), エジプト綿か らなるイムガード IG-400Y (Imugard IG-400Y : テルモ）で $400 \mathrm{~m} l$ 献血由来 RCC 1 単位をフィル ター処理した。イムガード IG-400Y では生理食塩 液 (大塚製薬, 東京) でプライミング・リンスを 行ったが，ポール RC100，七パセル R-500N およ びイムガード RCでは行わなかった。 セパセル R$500 \mathrm{~N}$ とイムガード RCでは当日血と 1 日保存 血, その他のフィルターでは 1 日保存血を, いず れも流量調節のクランプ全開で処理した。ポール RC100では，フィルター中の空気が抜けるまで圧 入した.

$\mathrm{PC}$ のィルター処理は, ポリエステル不織布 からなるポール PL100（Pall PL100）では20単位 の PC, 表面処理を施したポリエルテル不織布か らなるセパセル PL-5N (Sepacell PL-5N) とポリ ウレタン多孔質体からなるイムガード PL (Imugard PL) では10単位の PCをいずれも生理 食塩液によるプライミングなしで行った。 セパセ ル PL-5N ではフィルター処理後, 約 $50 \mathrm{~m} l$ の生理 食塩液でリンスした。イムガードIG-400Yは $\mathrm{RCC}$ の場合と同様にプライミングとリンスを行 いPC 20単位を処理した. RCC と同様にポール PL100は圧入をして，いずれのフィルターも流量 調節のクランプ全開で処理した.

3.フィルター処理血液製剂中の白血球の分 離・濃縮

フィルター処理した血液製剤は白血球濃度が低 くリンパ球サブポピュレーションの測定は困難で あるため, FCM で測定可能な程度まで白血球を 分離・濃縮した.フィルター処理 RCC は処理 $\mathrm{RCC} 2 \sim 3$ 単位まとめ, 等量の $\mathrm{Ca}^{2+} \cdot \mathrm{Mg}^{2+}$ 不 含 Hanks 液 (HBSS: Hanks' balanced salt solution) で希釈し，その $30 \mathrm{~m} l$ を $20 \mathrm{~m} l$ の FicollPaque (比重1.0777, Pharmacia, Piscataway, NJ, USA)に重層し, $380 \times \mathrm{g}$ で30分間遠心して単 
核球層を得た。この単核球層をすべてプールし, HBSS で洗浄し, さらにアルブミン添加 HBSS $(2 \% \mathrm{w} / \mathrm{v})$ で 2 回洗浄後、上清を約 $2 \mathrm{~m} l$ まで除去し てリンパ球サブポピュレーション測定用サンプル とした。

またフィルター処理 PCでは 20 単位分を $20 \mathrm{~m} l$ の33\%Percoll(比重1.04, Pharmacia, Uppsala, Sweden)に $20 \mathrm{~m} l$ ずつ重層して $127 \times \mathrm{g}$ で15分間遠 心し, 約 $200 \mu l$ まで上清を除去した。これを 1 本に まとめて, $1 / 10$ 量の $\mathrm{ACD}$ を加えたリン酸緩衝生 理食塩液 (PBS: $\mathrm{NaCl} 8.0 \mathrm{mg} / \mathrm{ml}, \mathrm{KCl} 0.2 \mathrm{mg}$ / $\mathrm{m} l, \mathrm{KH}_{2} \mathrm{PO}_{4} 0.2 \mathrm{mg} / \mathrm{m} l, \mathrm{Na}_{2} \mathrm{HPO}_{4} \cdot 7 \mathrm{H}_{2} \mathrm{O} 2.16$ $\left.\mathrm{mg} / \mathrm{m} l, \mathrm{NaN}_{3} 1.0 \mathrm{mg} / \mathrm{m} l, \mathrm{pH} 7.4\right)$ で 3 回洗浄 し， RCC と同様に約 $2 \mathrm{ml}$ まで上清を除去して, サ ンプルとした。

4. 白血球の組成とリンパ球サブポピュレー ションおよびサブセットの測定

試料 $100 \mu l$ に対して $2 \mathrm{~m} l$ の溶血液 $\left(\mathrm{NH}_{4} \mathrm{Cl} 8.26\right.$ $\mathrm{mg} / \mathrm{m} l, \mathrm{KHCO}_{3} 1 \mathrm{mg} / \mathrm{m} l$, EDTA- $4 \mathrm{Na} 37 \mu \mathrm{g} /$ $\mathrm{m} l, \mathrm{pH} 7.3 \therefore$ オーソ・ダイアグノステイック・シ ステムズ社, 東京) を加え, 擋拌後室温に 15 分間 静置した後, 白血球組成分析用サンプルとして レーザーフローサイトメター（ORTHO CYTORON : オーソ社) で測定した。測定は励起波長 488 $\mathrm{nm}$, レーザー出力 $15 \mathrm{~mW}$, サンプル流入速度 $1 \mu \mathrm{l} /$ 秒, シース液の流入速度を $6 \mathrm{~m} l /$ 分, 測定時間は60 秒とした. 前方散乱光抽よび $90^{\circ}$ 散乱光から顆粒 球, 単球, リンパ球の細胞比率を求めた。

上と同様に溶血した製剤から、リンパ球サブ

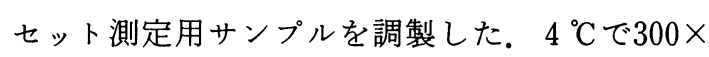
$\mathrm{g}, 10$ 分間遠心した後上清を除去し, 細胞を $4 \mathrm{~m} l$ の PBS で 2 回洗浄した. 上清を除去した後, PBSを 加えて元の血液量 $100 \mu l$ に合わせ, FITC(fluorescein isothiocyanate) 標識抗体, PE (phycoerythrin) 標識抗体各 $10 \mu l$, もしくは陰性コントロール (FITC 標識マウス免疫グロブリン) $10 \mu l$ を加え て二重染色し氷中で 30 分間静置した. $4 \mathrm{~m} l$ の PBS で洗浄, 上清を除去し細胞を $1 \mathrm{~m} l$ の PBS に再浮 遊した。この細胞浮遊液を CYTORON で測定時 間120秒で測定し,リンパ球領域に標示された細胞 の緑色蛍光 (FITC) と赤色蛍光 (PE) の陽性率を
求めた。

$$
\text { 5. モノクローナル抗体 }
$$

各モノクローナル抗体はオーソミューン OK シリーズ (オーソ社)を用いた. OKT3 (CD3) は ヒト末梢血 T リンパ球と反応し, OKT4 (CD4), OKT8(CD8)は各々, 主にヒト末梢血のールパー/ インデューサーT リンパ球, サプレッサー/細胞 障害性 T リンパ球と反応する。 OKB20（CD20） はヒトBリンパ球を, OKNK (CD16) はLGL (large granular lymphocyte) を含む $\mathrm{NK} / \mathrm{K}$ 細胞 や顆粒球を識別する。本研究では OKT8 (FITC) と OKT4 (PE), OKB20 (FITC) と OKT3 (PE), OKNK (FITC) と OKT3 (PE) を組み合わせて 行った.

\section{6. 白血球数の測定}

試料 $100 \mu l$ を $750 \mu l$ のプロピディウムイオダイ ド (PI : propidium iodide) 溶液 (PI $50 \mu \mathrm{g} / \mathrm{m} l$, ribonuclease A $1 \mathrm{mg} / \mathrm{m} l$, sodium citrate monobasic $1 \mathrm{mg} / \mathrm{m} l$, Triton X-100 $1 \mu l / \mathrm{m} l$, 各々 PBS 中の最終濃度) に加えて, 室温で10分間反応 させ, 前方散乱光と赤色蛍光強度のサイトグラム を得, 白血球数を計測した ${ }^{21)}$.

\section{7. 統計処理}

フィルター処理前後のリンパ球サブポピュレー ション, サブセットの差の検定は, 対応のある場 合の $\mathrm{t}$ 検定を用い, $\mathrm{p}<0.05$ を有意な差とした。

\section{結 果}

1. 血液製剤中の白血球組成拉よびリンパ球サ ブポピュレーションとサブセット

$400 \mathrm{~m} l$ 献血由来の $\mathrm{WB} ・ \mathrm{RCC} ・ \mathrm{PC}$ ，抒上びア フェレーシス $\mathrm{PC}$ 中の白血球組成を調べた（表 1). WB と RCC はリンパ球 (WB $45.9 \pm 2.6 \%$, RCC $43.1 \pm 2.7 \%$ ) と顆粒球 $(50.4 \pm 2.4 \%, 53.5 \pm$

表 1 血液製剤中の白血球組成

\begin{tabular}{l|c|c|c}
\hline & $\begin{array}{c}\text { リンパ球 } \\
\text { (\%) }\end{array}$ & $\begin{array}{c}\text { 単 球 } \\
(\%)\end{array}$ & \multicolumn{1}{c}{$\begin{array}{c}\text { 顆粒球 } \\
(\%)\end{array}$} \\
\hline $\mathrm{WB}^{*}$ & $45.9 \pm 2.6$ & $3.7 \pm 0.5$ & $50.4 \pm 2.4$ \\
$\mathrm{RCC}^{*}$ & $43.1 \pm 2.7$ & $3.4 \pm 0.6$ & $53.5 \pm 2.3$ \\
$\mathrm{PC}^{* *}$ & $89.0 \pm 1.6$ & $5.2 \pm 0.5$ & $5.8 \pm 1.5$ \\
アフェレーシス $\mathrm{PC}^{* *}$ & $96.4 \pm 0.8$ & $2.3 \pm 0.2$ & $1.3 \pm 0.7$ \\
\hline
\end{tabular}

平均 $\pm 1 \mathrm{SE}{ }^{*}: \mathrm{n}=5,{ }^{* *}: \mathrm{n}=7$ 
$2.3 \%)$ によって白血球全体の $95 \%$ 以上が占められ るが，PCでは全血由来・アフェレーシス共にリン パ球がそれぞれ $89.0 \pm 1.6 \% ， 96.4 \pm 0.8 \%$ とその 大部分を占め, 顆粒球の混入は $5.8 \pm 1.5 \%, 1.3 \pm$ $0.7 \%$ とわずかであった。

またリンパ球のサブポピュレーションは，B細

表 2 血液製剤中のリンパ球サブポピュレーション およびサブセット

\begin{tabular}{|c|c|c|c|c|}
\hline & $\mathrm{WB}^{*}$ & $\mathrm{RCC}^{*}$ & $\mathrm{PC}^{*}$ & $\begin{array}{c}\text { アフェレーシス } \\
\mathrm{PC}^{* * *}\end{array}$ \\
\hline T細胞 $(\%)$ & $62.2 \pm 2.6$ & $62.3 \pm 2.4$ & $65.4 \pm 1.3$ & $70.3 \pm 1.6$ \\
\hline B 細胞 (\%) & $9.4 \pm 1.2$ & $9.7 \pm 1.2$ & $14.7 \pm 1.4$ & $16.6 \pm 1.2$ \\
\hline $\mathrm{T} / \mathrm{B}$ & $7.3 \pm 0.6$ & $7.1 \pm 0.7$ & $4.9 \pm 0.6$ & $4.5 \pm 0.4$ \\
\hline T紐胞 (\%) & $61.9 \pm 2.3$ & $61.5 \pm 1.6$ & $64.2 \pm 1.4$ & $68.0 \pm 1.5$ \\
\hline NK 細胞 (\%) & $18.5 \pm 2.1$ & $20.1 \pm 1.8$ & $17.9 \pm 1.7$ & $11.1 \pm 1.6$ \\
\hline $\mathrm{T} / \mathrm{NK}$ & $3.9 \pm 0.6$ & $3.4 \pm 0.4$ & $4.1 \pm 0.6$ & $7.6 \pm 0.9$ \\
\hline $\mathrm{CD}^{+}(\%)$ & $39.2 \pm 2.4$ & $37.5 \pm 2.3$ & $41.9 \pm 2.0$ & $43.2 \pm 1.8$ \\
\hline $\mathrm{CD}^{+}(\%)$ & $26.6 \pm 1.1$ & $26.5 \pm 0.8$ & $24.1 \pm 1.4$ & $26.3 \pm 1.6$ \\
\hline $4^{+/} / 8^{+}$ & $1.5 \pm 0.2$ & $1.4 \pm 0.1$ & $1.8 \pm 0.2$ & $1.8 \pm 0.2$ \\
\hline
\end{tabular}
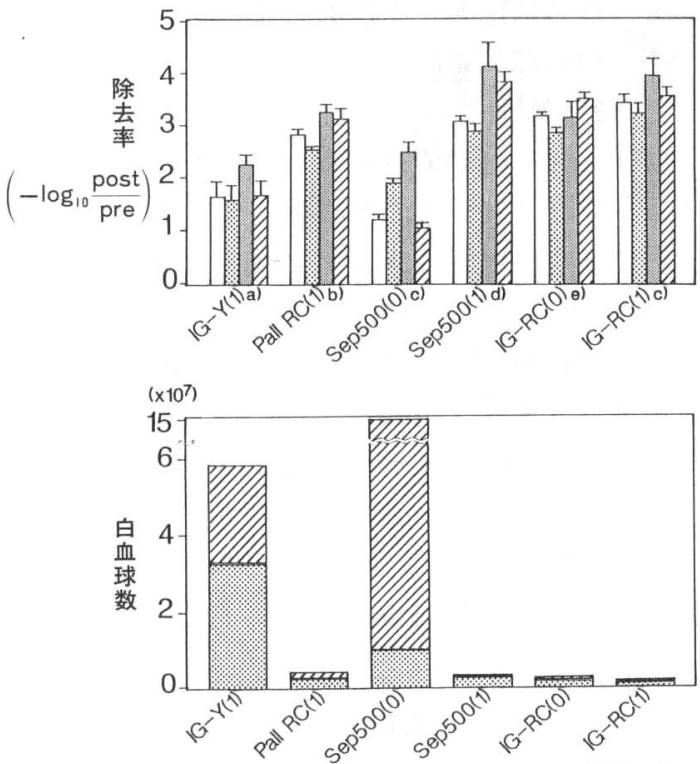

$\square$ 総白血球 图リンパ球 口単球【顆粒球

図 1 フィルター処理濃厚赤血球の白血球除去率(上) と 1 バッグ当りの残存白血球数(下). 白血球除去率 は平均 $+1 \mathrm{SE}$. (0)：当日血，(1)：1日保存血. $\mathrm{n}$ 数 (は a) :3, b) : 4, c) :5, d) : 7, e) :6. IG-Y : イ ムガードIG-400Y, Pall RC：ポール RC100, Sep500：セパセル R-500N, IG-RC：イムガード RC
胞はWBで全りンパ球の $9.4 \pm 1.2 \%, \mathrm{RCC}$ で $9.7 \pm 1.2 \%$ であったのに対し，全血から調製した $\mathrm{PC}$ およびアフェレーシス PCではやや多い傾向 を示し各々 $14.7 \pm 1.4 \%, 16.6 \pm 1.2 \%$ であった(表 2). NK 細胞はアフェレーシス PCでは全リンパ 球の $11.1 \pm 1.6 \%$ で,その他の製剤(17.9 20.1\%) よりもやや少ない傾向がみられた。またリンパ球

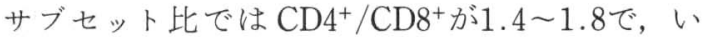
ずれの製剤についても核に゙同じ值が得られた。

2.フィルター処理による白血球除去率と残存 白血球数

当日あるいは 1 日保存 RCC を各種フィルター で処理した際の白血球除去率および漏出総白血球 数を図 1 に示した。全般に単球の除去率が最も高 く, 次いで顆粒球，リンパ球の順であった。 セパ 七ル R-500N による当日血処理では白血球の除去 率は93.2\%と低く，この原因は顆粒球の漏出によ るものであった。しかし 1 日保存血では除去率は 他フィルターと同等以上の成績を示した。イム ガード RC は当日血抢よび保存血双方に高い白血
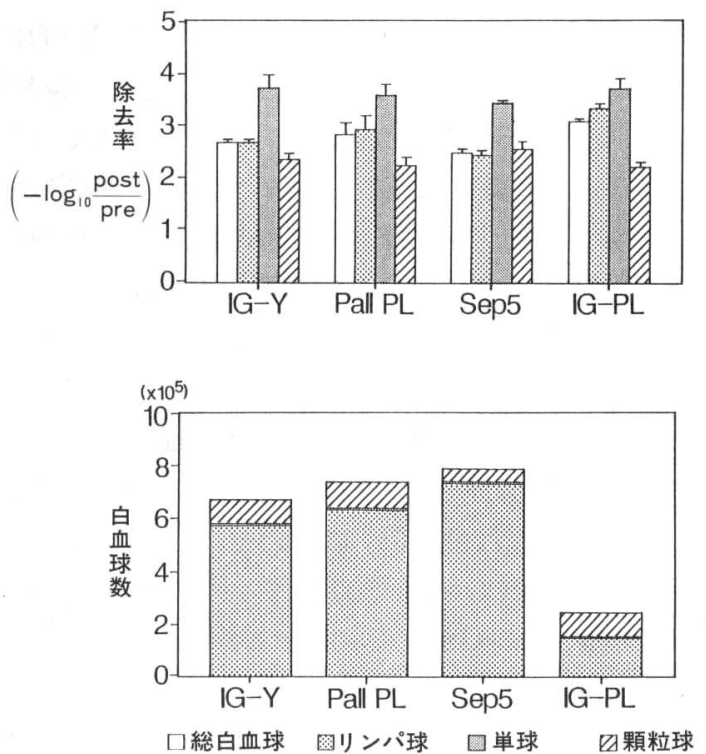

図 2 フィルター処理濃厚血小板の白血球除去率(上) と20単位当りの残存白血球数(下). $n=4$, 白血球除 去率は平均 $+1 \mathrm{SE}, \mathrm{IG} \cdot \mathrm{Y}$ ：イムガードIG-400Y, Pall PL：ポール PL100, Sep5：セパセル PL-5N, IG-PL：イムガードPL 
球除去率を示し, 保存条件の違いよる大きな差は 認められなかった。 セパセル R-500N 当日血処理 での漏出白血球総数は, $1.5 \pm 0.4 \times 10^{8}$ 個，イム ガード IG-400Y で $5.8 \pm 2.9 \times 10^{7}$ 個，その他はい ずれも $4 \times 10^{6}$ 個以下であった。

$\mathrm{PC}$ 用フィルター 4 種の白血球除去率および漏 出総白血球数を図 2 に示した。いずれのフィル ターでも RCC 用フィルターと同様に単球が最も 良く除去された。一方顆粒球の除去率は単球に比 較して低かった。イムガード PLは白血球除去率 99.91\% (3.07 $\left.\log _{10}\right)$ と最も良い成績を示し，20単 位 $\mathrm{PC}$ 中の漏出白血球数は他のフィルターでは $7 \sim 8 \times 10^{5}$ 個であったのに対して $2.5 \pm 0.8 \times 10^{5}$ 個 であった。

3.フィルター処理血液製剂中のリンパ球サブ ポピュレーションおよびサブセット

Ficoll-Paque 処理して得られた単核球層に拉 ける白血球の回収率はフィルター処理 RCC の全 白血球の $11.4 \pm 1.5 \%(\mathrm{n}=35)$ であったが，これ は白血球のうち顆粒球がこの処理によって除かれ たためである。また Percoll 処理によるフィル タ一処理 PC 全白血球からの回収率は55.6土 7.5\%（n=23）であった。しかし濃縮を必要とし ない細胞濃度による予備検討により，これら比重 分離法処理の前後におけるリンパ球の種類とサブ セットの違いは測定結果に対して影響を与えない ことを確認した。

(1) Tリンパ球と B リンパ球

RCC フィルター処理に拈いてはポール RC100 を除くすべてのフィルターで， Tリンパ球/Bリ ンパ球比は処理後に有意に高い值を示した（図 3).イムガード RCでは特に当日血（処理前 $\mathrm{T} /$

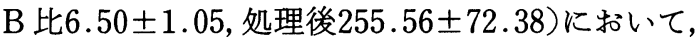

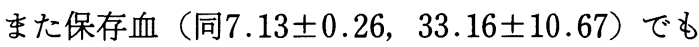
顕著な差がみられ, B リンパ球が T リンパ球に比 ベてフィルターにより除去されやすいことがわ かった.

PCフィルター処理では, イムガードIG-400Y で処理後に $\mathrm{T} / \mathrm{B}$ 比は有意に高い值が得られた。 またセパセル PL-5N とポールPL100でも処理後 の方が高くなる傾向が認められたが，イムガード PL ではその差はほとんど認められなかった。

（2） NK 細胞

$\mathrm{NK}$ 細胞は，七パセル R-500N とイムガード

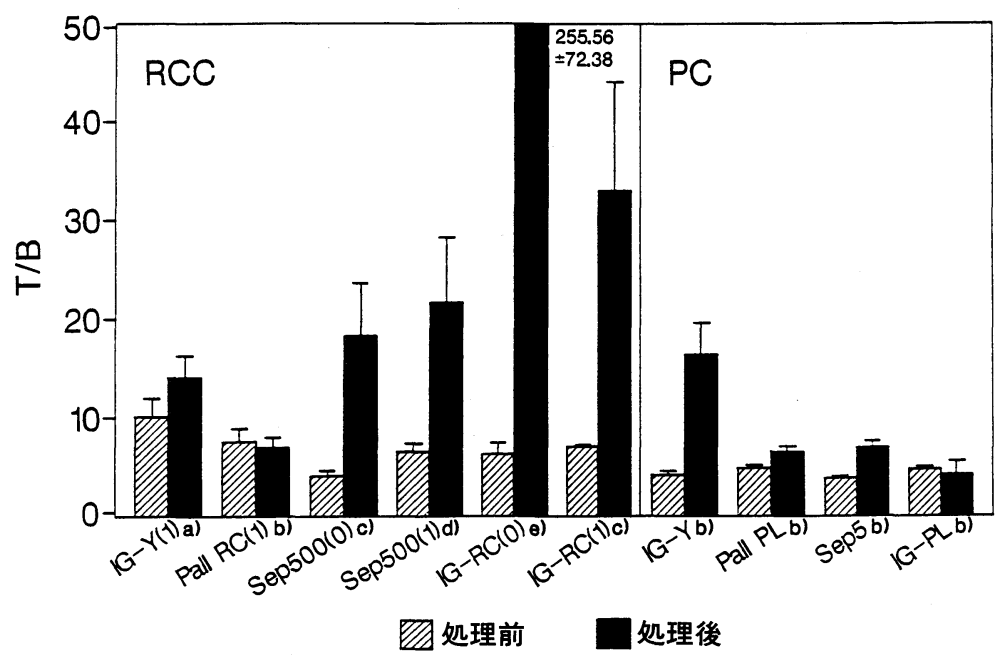

図 3 フイルター処理 RCC および PC 中の $\mathrm{T} / \mathrm{B}$ 細胞比. 平均+1SE. RCC : 当日血 (0)，1 日保存血 (1). n 数は, a) :3, b) :4, c) :5, d) :7, e) :6. IG-Y：イム ガードIG-400Y, Pall RC：ポール RC100, Sep500：セパセル R-500N, IG-RC：イ ムガード RC, Pall PL：ポール PL100, Sep5：セパセル PL-5N, IG-PL：イムガー ド PL 


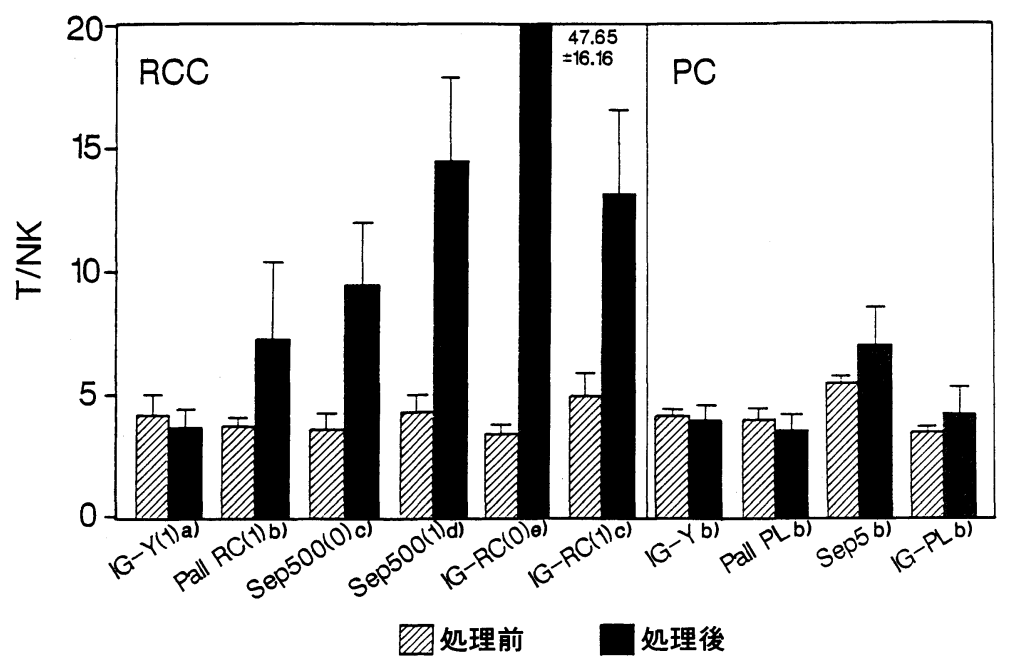

図 4 フィルター処理 RCC 抽よび PC 中の $\mathrm{T} / \mathrm{NK}$ 細胞比. 平均 $+1 \mathrm{SE}$. RCC : 当日血 (0), 1 日保存血 (1). n 数は a) : 3, b) :4, c) :5, d) :7, e) :6. IG-Y：イムガー ドIG-400Y, Pall RC:ポールRC100, Sep500：セパセル R-500N, IG-RC：イム ガード RC, Pall PL：ポール PL100, Sep5：セパセル PL-5N, IG-PL：イムガード PL

$\mathrm{RC}$ で処理した場合 $\mathrm{T}$ 細胞よりも有意に除去され やすい傾向が認められた（図 4 ). 処理後の $\mathrm{T}$ 細 胞/ $\mathrm{NK}$ 細胞比は, セパセル R- $500 \mathrm{~N}$ では当日血

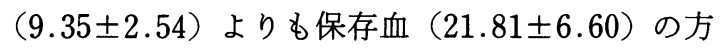
が大きかったが，イムガード RCでは逆に保存血 (13.10士3.45) よりも当日血 $(47.65 \pm 16.16)$ の 方が大きな值が得られた。ポール RC100でも T/ NK 比は処理後に高くなる傾向はあったが，有意 差は得られなかった。

PC 用フィルターではいずれのフィルターでも $\mathrm{T} / \mathrm{NK}$ 比に処理前後で有意差は認められなかっ たが，セパセル PL-5N で処理後 $(6.86 \pm 1.55)$ の 方が処理前 (5.06 \pm 0.35$)$ に比べてやや高い値を 示す傾向が得られた.

(3) $\mathrm{CD}^{+}$と $\mathrm{CD} 8^{+} \mathrm{T}$ リンパ球

$\mathrm{RCC}$ においてはセパセル R-500N で当日血処 理，イムガード RCでは当日血打よび保存血処理 の双方で, $\mathrm{CD}^{+} / \mathrm{CD} 8^{+}$比にフィルター処理前の $\mathrm{RCC}$ 中のリンパ球に比べて有意に高い值が得ら れこの条件下で $\mathrm{CD} 8^{+}$細胞が $\mathrm{CD} 4^{+}$細胞よりフィ ルターに捕捉されやすいことがわかった（図 5 ). 中でもイムガード RCによる当日血処理では
$5.55 \pm 1.41$ と, 処理前 $(1.44 \pm 0.15)$ の約 4 倍の $\mathrm{CD}^{+} / \mathrm{CD} 8+$ 值が得られた。

一方 PCではいずれのフィルターを用いた場合 にも処理前に対して処理後の $\mathrm{CD} 4^{+} / \mathrm{CD}^{+}$值は有 意に高く,イムガード PL で5.25 0.75 , その他の

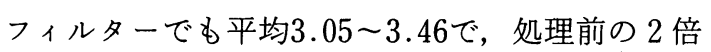
以上であった。

\section{考 察}

全血由来 PC，アフェレーシス PCにおいては, 混在白血球のほとんどがリンパ球によって占めら れており,顆粒球はわずかしか混入していない(表

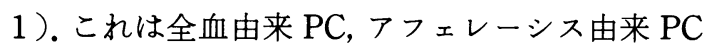
のどちらに扣いても遠心という物理的条件により 調製されているため, 比重の大きい顆粒球は PC 中に混在しにくいと考号れる。

健常人末梢血中のリンパ球は, $\mathrm{T}$ 細胞が $54 \sim 88 \%$, B 細胞 $7 \sim 27 \%, \mathrm{NK}$ 細胞 $7 \sim 37 \%$, $\mathrm{CD}^{+} 31 \sim 60 \%, \mathrm{CD}^{+} 21 \sim 36 \%$ と報告されてい る ${ }^{26)}$. 今回我々が測定した WB, RCC, PC の血液 製剤中のリンパ球サブポピュレーションを比較す ると, 全血由来, アフェレーシス由来 PC中に B 細胞がやや多く, アフェレーシス PC 中に NK 細 


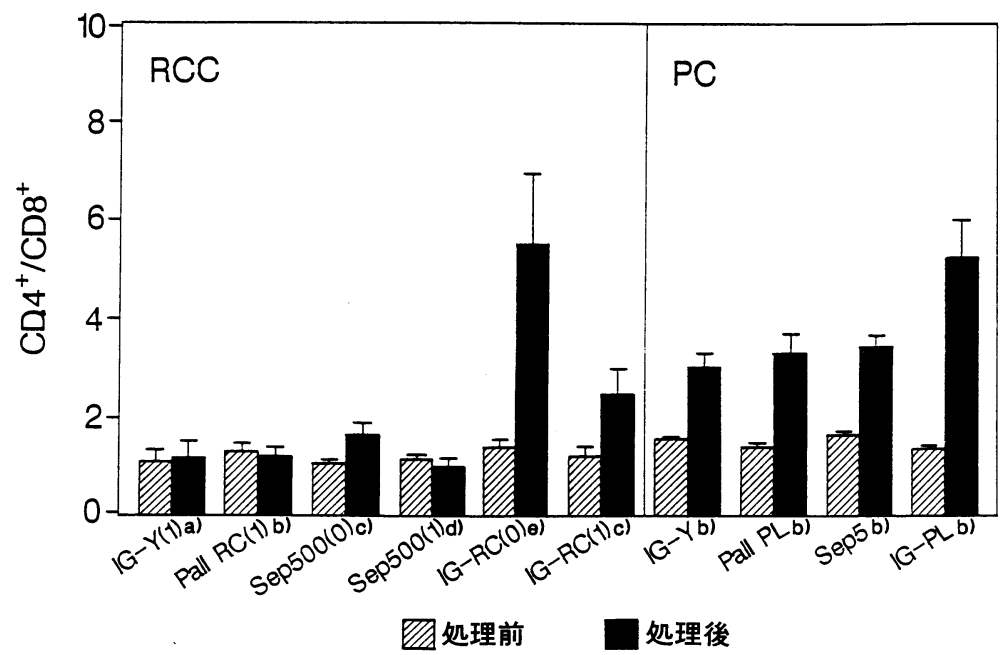

図 5 フィルター処理 $\mathrm{RCC}$ および $\mathrm{PC}$ 中の $\mathrm{CD} 4^{+} / \mathrm{CD} 8^{+} \mathrm{T}$ リンパ球比. 平均+ $1 \mathrm{SE}$. $\mathrm{RCC}$ : 当日血 (0), 1 日保存血 (1). $\mathrm{n}$ 数は a)：3, b)：4, c)：5, d)：7, e)：6. IG-Y：イムガードIG-400Y, Pall RC：ポール RC100, Sep500：セパセル R-500N, IG-RC：イムガードRC, Pall PL：ポール PL100, Sep5：セパセル PL-5N, IGPL：イムガード PL

胞がやや少ない傾向が得られた(表 2 )。この傾向 が各リンパ球の比重や大きさの違いによるものな のかどらか, またアフェレーシス機器の違いにに

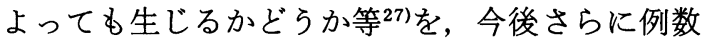
を増やして確認していく必要があると思われる。 RCC 执よび PCからのフィルターによる白血球 除去を進めていく場合は，このような血液製剂間 の混在白血球の種類の違いを認識することが必要 である。

セパセル R-500N による RCC 当日血処理では 顆粒球が多く漏出し，その結果全体の白血球除去 率が低下している(図 1)。この当日血処理に打け る顆粒球漏れの現象 ${ }^{16) 28}$ ) は, 同種の素材 (ポリエス テル不織布）からなるポール RC50フィルター (Pall Co.) でも同様な結果が得られている（北海 道血液センター：未発表データ).ポリビニール多 孔質体からなるイムガード RCフィルターではこ のような現象がみられないことは，不織布と多孔 質といらフィルター材質の違いを反映していると

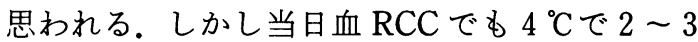
時間冷却した後に室温にてセパセル R-500N フィ ルター処理した場合には顆粒球の漏出はかなり減
少し ${ }^{16)}$ ，また不織布の充填密度を高めた実験用 フィルターR-S350（旭メディカル）では当日血で 室温処理でも顆粒球漏れがほとんど起こらな (29).このことから顆粒球の漏れは, 顆粒球自身の 能動的なフィルターの通り抜けに起因するのかも しれない。

1 日保存した PCをイムガード IG-400Y およ びセパセル PL-5N でフィルター処理した場合に は, 漏出白血球の内でリンパ球の占める割合が RCC に比較して大きいが（図 2)，これはフィル ター処理前の $\mathrm{PC}$ 中に含まれる白血球はリンパ球 がほとんどを占めること（表 1 ）を反映している ためと考えられる。

従来第二世代の白血球除去フィルターとしてェ ジプト綿からなるイムガード IG-400Y が RCC お よび PCからの白血球除去に多く使用されてきた が，白血球除去率は同種免疫を防ぐ上で必ずしも 十分ではなく，その内容量から赤血球の損失も大 きく血小板の吸着も免れない，第三世代の白血球 除去フィルターであるセパセル R-500N やポール $\mathrm{RC}$ は, 微細ポリエステル繊維を不織布化するこ とにより白血球の除去率を高め，またフィルター 
の内容量の減少に寄与している，不織布による白 血球除去は第一に白血球の繊維への受動的吸着, 次に密な繊維空間による捕獲(ふるい分け)，第三 に白血球の能動的粘着が考えられる ${ }^{30)}$.一方ポ リービニルアルコール系多孔質体からなるイム ガード RCの場合は，ふるい分けが吸着に加えて 大きな要素となると考えられる. Steneker と Biewenga $^{31)}$ は不織布からなる 3 種のフィルター を使用し，フィルター内の各層に残存する白血球 の種類を同定し，白血球除去の機構を考察してい る.それによると顆粒球, 単球は主に吸着によっ て除去されるが，リンパ球についてはふるい効果 により除去される場合（ポール RC100）と吸着に よっても除去される場合（セパセル R-500）がある と報告されている. RCC, PC 用フィルター処理で はほとんどの場合, 単球の除去率が最も高かった が(イムガード RC 当日血処理を除く)，これは単 球が他の細胞に比べてサイズが大きいといら要素 に加えて, 単球の特徴である強い付着性を反映し ていると考えられる。フィルター処理により単球 と B 細胞が除去されやすいことはVakkila と Myllyla の報告 ${ }^{32)}$ と一致する。単球の除去率が高 $く, \mathrm{~B}$ 細胞が $\mathrm{T}$ 細胞より (図 3 ), $\mathrm{CD} 8^{+}$細胞が $\mathrm{CD} 4+$ 細胞より除去されやすい (図 5 ) といら結果 からは，細胞の大きさに依存したふるい分け効果 に加えて細胞吸着が白血球除去機構においてフィ ルターの材質を問わず大きな要素となっていると いえよう。

フィルター処理によるリンパ球のサブセットの 特異的な除去についてはリンパ球アフェレーシス によって得られた多リンパ球血漿をセパセル R500 とイムガード IG-500 (エジプト綿)で処理した 吉田らの報告がある ${ }^{33)}$. そこではリンパ球含有率 が極めて高いため除去率は本研究よりは低く同一 のレベルでの比較は難しいが，単球が除去されや すいこと, 両フィルターで B 細胞, $\mathrm{CD} 8+$ 細胞が除 去されや寸い等, 除去の特異性は本研究と一致し た結果がみられる。

ポール RC100とセパセル R-500N はいずれも ポリエステル不織布からなるが, 除去される細胞 の特異性は $\mathrm{B}$ 細胞除去能に特に差がみられ（図
3 )両フィルターで若干異なっている。ポール RC フィルターがポリェステル繊維の表面を放射線グ ラフトでコートしてあるのに対し，セパセル R$500 \mathrm{~N}$ ではそのような処理がなされていないが, この結果は不織布繊維の表面荷電と細胞付着の関 係等を調べていく上での手がかりになるかもしれ ない。

不織布からなる PC 用フィルターでは血小板の 吸着を防ぐため不織布表面がポリマーでューティ ング処理（セパセル PL）あるいは放射線グラフト 重合により繊維表面を水酸基化して（ポール PL） いるため，特定の細胞が除去される傾向は RCC 用フィルターに比べて少ないと予想された。たし かにセパセル PLに拈いてはB 細胞への特異性 は減少して拈り（図 3 ), 特に NK 細胞の除去率は セパセル，ポールの両 PC用フィルターで RCC 用フィルターに比べて減少していた(図 4 )。 しか し $\mathrm{CD} 8^{+}$が $\mathrm{CD} 4^{+}$よりも除去される傾向（図 5 ）は $\mathrm{PC}$ 用フィルターの方がより顕著であった。現在 のところ $\mathrm{CD}^{+}$細胞と $\mathrm{CD} 8^{+}$細胞に大きさ，付着性 に違いがあるといら確証は得られて招らず，この 結果を説明するには細胞側とフィルタ一材質の両 方からさらに詳細な研究を進める必要がある。

多孔質体フィルターであるイムガード RC とイ ムガード PL は材質, 多孔質の形状が異なるため, 白血球除去の機構をこの両者の結果から類推する のは難しいが, $\mathrm{CD} 8+$ の特異性は両者ともあるもの の(図 5 ), B 細胞および NK 細胞への特異性がポ リビニルアルコール系多孔質体からなるイムガー ド RCで不織布フィルターに比べても極めて大き いのは(図 3，4), 細胞の大きさより吸着性の違 いがこの結果を導いている可能性が大きいと考兄 られる。

以上のようにフィルター処理によっても漏出し てくる白血球の種類はフィルターの種類によっ て，また処理する RCCの保存日数によっても違 いがあるが, 同一条件下では同じ傾向がみられる。 現在まで報告されているフィルターを用いた同種 免疫予防の in vivo 実験を残存白血球の種類を考 慮して見直すことは，意義のあることと考える. 白血球の中で MHCクラスII抗原を発現してい 
る単球が極めて除去されやすく，また B 細胞が比 較的除去されやすいといらことは，クラス II抗原 陽性の細胞が主たる免疫原といわれている同種免 疫の予防の上では大きな意味のあることと思われ る.末梢血中の樹状細胞 (dendritic cell) は抗原 提示細胞として重要であるが，末梢血中の数がき わめて少ないことと特定のマーカーがないため ${ }^{34)}$ 今回検討できなかったが，フィルター処理により この dendritic cell が除かれやすいという報告も 見られる ${ }^{35)}$ 。また $\mathrm{CD} 8+$ 細胞がよりよく除去され ることは, GVHD の発症に何らかの影響を与える 可能性が考えられる。 また特異的な白血球に宿す ウイルスによる輸血感染の防止にも効果があるか も知れない。

漏出してきたリンパ球はフィルターを通過して いる間に傷害を受け，培養を続けることができな い結果が得られている ${ }^{13)}$ 。 な HTLV 陽性血を フィルター処理した場合の漏出白血球は HTLVI 感染能を失う結果が得られている ${ }^{36)}$. 今後は フィルター処理によっても漏出してきたそれぞれ のリンパ球の性状がどら変化しているかをさらに 詳細に検討していくことが必要であると考える。

\section{結語}

（1）フローサイトメトリーによる血液製剤中の 白血球の組成を明らかにした，WB と RCC の白 血球組成はほぼ一致するが, PCは全血由来, ア フェレーシスともにリンパ球がその大半を占めて いた。またリンパ球サブセットは WB, RCC, PC 間で大差は認められなかった。

（2）白血球除去フィルター処理では RCC，PC ともに単球が最も高率に除去された。

（3） RCC 用フィルター中，セパセル R- $500 \mathrm{~N}$ お よびイムガード RCでは $\mathrm{B}, \mathrm{NK}$ 細胞および $\mathrm{CD} 8+$ がより除去された。 $\mathrm{PC}$ 用フィルターでは, イムガード IG-400Y では B 細胞が除去されやす い傾向がみられたが，他のフィルターでは特異性 は認められなかった。 またいずれのフィルターで も $\mathrm{CD} 8^{+}$が CD4+に比べて良く除去された。

血液製剂中の，またフィルター処理により白血 球除去した製剤中の混入白血球を同定すること は, 輸血副作用の予防, 発症のメカニズムの解明,
またより効果的な白血球除去フィルターの開発に 役立つと考えられる。

\section{文献}

1) 関口定美: 臟器移植と術前・術後の輸血. 今日の 移植, 2: 357-365, 1989.

2) Meryman, H.T.: Cleaning up red cells and platelet: Alloimmunization, immunosuppression and disease transmission. In McCarthy, L. J., Baldwin, M.L. (Eds.) : Controversies of Leukocyte-Poor Blood and Components, p. 1 -26, American Association of Blood Banks, Arlington, 1989.

3) Sirchia, G., Rebulla, P., Parravicini, A., Carnelli, V., Gianotti, G.A. and Bertolini, F. : Leukocyte depletion of red cell units at the bedside by transfusion through a new filter. Transfusion, $27:$ 402-405, 1987.

4) Sirchia, G., Wenz, B., Rebulla, P., Parravicini, A., Carnelli, V. and Bertolini, F.: Removal of white cells from red cell by transfusion through a new filter. Transfusion, $30: 30-33,1990$.

5) Reverberi, R. and Menini, C.: Clinical efficacy of five filters specific for leukocyte removal. Vox Sang., 58 : 188-191, 1990.

6) Fisher, M., Chapman, J.R., Ting, A. and Morris, P.J.: Alloimmunization to HLA antigens following transfusion with leucocyte-poor and purified platelet suspensions. Vox Sang., 49: 331-335, 1985.

7) Myllylä, G.: Leuco-Depletion: The Finish Experience, Presented at the Meeting of British Blood Transfusion Society on the Aspects of Blood Filtration, Birmingham, U.K., 1990.

8) Saarinen, U.M., Kekomäki, R., Siimes, M.A. and Myllylä, G.: Effective prophylasis against platelet refractoriness in multitransfused patients by use of leukocyte-free blood components. Blood, 75 : 512-517, 1990.

9) de Graan-Henzen, Y.C.E., Gratama, J.W., Mudde, G.C., Verdonck, L.F., Houbiers, J.G.A., Brand, A., Sebens, F.W., van Loon, A.M., The, T.H., Willemze, R. and de Gast, G.C.: Prevention of primary cytomegalovirus infection in patients with hematologic malignancies by intensive white cell depletion of blood products. Transfusion, 29 : 757-760, 1989.

10) Okochi, K. and Sato, H.: Transmission of adult T-cell leukemia virus (HTLV-I) through blood transfusion and its prevention. AIDS Research, 2 : 157-161, 1986.

11) Douglas, S.D. and Fudenberg, H.H.: Graft 
versus host reaction in Wiskott-Aldrich syndrome: Antemortem diagnosis of human GVH in an immunologic deficiency disease. Vox Sang., $16: 172-178,1969$.

12）高橋孝喜, 十字猛夫：輸血による GVHD. 外科診 療, $33: 369-376,1991$.

13) Sekiguchi, S. and Takahashi, T.A.: Leucocyte-depleted blood products and their clinical usefulness, In Brozović. B. (Ed.): The Role of Leukocyte Depletion in Blood Transfusion Practice, p. 26-34, Blackwell Scientific Publication, Oxford, 1989.

14）池田康夫, 半田 誠：血液製剂からの白血球除去. Immunohaematology, $11:$ 145-152, 1989.

15）武部道和, 羽富智司, 坪倉兌雄：イムガード $\mathrm{E} を$ 用いた白血球除去濃厚赤血球の調製.日輸血会誌, $35: 622-626,1989$.

16）瀬川紀美子, 長谷川秀弥, 細田真理, 高橋恒夫, 関口定美 : 新しい白血球除去フィルターイムガー ド Eの性能. セパセル R-500N との比較. 日輸血 会誌, $36: 497-503,1990$.

17）宮本正樹, 石川善英, 小川篤子, 西村隆雄, 黒田 徹: 血小板輸血用白血球除去フィルターの開発. 日輸血会誌, $35: 370-374,1989$.

18）高橋恒夫, 細田真理, 茂木祐子, 黒木 壬, 黒田 慎一郎, 佐渡峯生, 関口定美：イムガード PL(ポ リウレタン多孔質体フィルター) による濃厚血小 板製剂中の白血球除去. 日輸血会誌, $37: 24-31$, 1991.

19）高橋恒夫, 細田真理, 関口定美：フィルターによ る濃厚血小板製剤からの白血球除去一Pall PL100 及び Pall PL50 の評価一. 医科器械学, 60 : $351-357,1990$.

20）高橋恒夫, 細田真理, 関口定美: サイトスピン法. 白血球除去濃厚血小板中の残存白血球数の新しい 確認法. 日輸血会誌, 35: 497-503, 1989.

21）高橋恒夫, 細田真理, 関口定美 : フローサイトメ トリーによるフィルター処理白血球除去血液製剂 中の残存白血球数の確認. 日輸血会誌, $36: 429$ $-437,1990$.

22) Bodensteiner, D.C.: A flow cytometric technique to accurately measure postfiltration white blood cell counts. Transfusion, 29: 651 -653, 1989.

23) Dzik, W.H., Ragosta, A. and Cusack, W.F.: Flow-cytometric method for counting very low numbers of leukocytes in platelet products. Vox Sang., 59: 153-159, 1990.

24) Wenz, B., Burns, E.R., Lee, V. and Miller W.K. : A rare-event analysis model for quantifying white cells in white cell-depleted blood. Transfusion, 31 : 156-159, 1991.
25) Sadoff, B.J., Dooley, D.C., Kapoor, V., Law, P., Friedman, L.I. and Stromberg, R.R. : Methods for measuring a $6 \log _{10}$ white cell depletion in red cells. Transfusion, $31: 150-155,1991$.

26）中原一彦：臨床検査ガイド. 文光堂, 東京, 1990 , p. $747-754$.

27）篠沢 隆, 涉谷温, 小田部裕恵, 市川洋一： IBM2997を用いた血小板および顆粒球採取時の 供血者ならびに採取バッグ中のリンパ球サブセッ ト、日輸血会誌, 33: 503-506, 1987.

28）宮本正樹, 柴 雅之, 村徹, 笹川 滋：セパ セル-R500による濃厚赤血球からの白血球除去 一分離能に及ぼす保存日数の影響一.日輸血会誌, $36: 567-573,1990$.

29）高橋恒夫, 細田真理, 岡慎一郎, 西村隆雄, 茂木 祐子, 那須百代, 千葉清司, 山脇直邦, 関口定美 : 高性能白血球除去フィルターR-S350の開発とそ のクローズドシステム化. 日輸血会誌, $37: 232$, 1991.

30）高橋恒夫, 細田真理, 茂木祐子, 関口定美: フィ ルターによる白血球除去血液製剂の調製。血液事 業 Blood Programme, 14 : 311-316, 1991.

31) Steneker, I. and Biewenga, J.: Histologic and immunohistochemical studies on the preparation of white cell-poor red cell concentrates: the filtration process using three different polyester filters. Transfusion, $31: 40-46,1991$.

32) Vakkila, J. and Myllylä, G.: Amount and type of leukocytes in 'leukocyte-free' red cell and platelet concentrates. Vox Sang., 53: 76 $-82,1987$.

33）吉田久博, 伊藤和彦, 内野治人：治療的 filtration lymphocytapheresis のための基礎的検討. 日輸血 会誌, $32: 389-393,1986$.

34) Freudenthal, P.S. and Steinman, R.M.: The distinct surface of human blood dendritic cells, as observed after an improved isolation method. Proc. Natl. Acad. Sci. U.S.A., 87 : 7698 $-7702,1990$.

35) Freedman, J., Blanchette, V., Hornstein, A., Farkas, S., Milner, R., Adams, M., Lim, F.C., Garvey, B. and Hannach, B.: White cell depletion of red cell and pooled random-donor platelet concentrates by filtration and residual lymphocyte subset analysis. Transfusion, 31 : 433-440, 1991.

36）小林正友, 矢野美佐子, 高橋恒夫, 権 吉源, 池 田久實, 関口定美: Sepacell フィルターを用いた HTLV-I感染白血球除去の検討一PCR 及び syncytium induction assayによる評価一。日輸 血会誌, $37: 272,1991$. 